\title{
КЛАСИФІКАЦІЇ СКВЕРІВ ТА ЇХ РОЗПОДІЛ У КОМПЛЕКСНІЙ ЗЕЛЕНІЙ ЗОНІ ЛЬВОВА
}

Наведено результати досліджень репрезентативної вибірки скверів міста Львова та висвітлено їх роль в урбанізованому середовищі. За натурними дослідженнями та картографічними матеріалами розроблено класифікацію скверів Львова за ознаками - зовнішнім виглядом, розташуванням, функціями та часом створення, а також за групами та підгрупами. Наведено кількість, площе та приналежність скверів міста до адміністративних районів міста. Здійснено класифікацію скверів за орографічною приналежністю та місцем створення. Проведено розподіл скверів міста за зовнішнім виглядом - розміром-площею, формою, плануванням і за складом насаджень. Здійснено класифікацію скверів Львова за функціями - транзитні, відпочинкові, буферні, спортивні, лікарняні, декоративні, пам'ятні, а також за часом створення - старовинні (до початку XX ст.), старі (від початку до 50-х років XX ст.), нові (від 50-х років до кінця XX ст.), новітні (2000-2015 рр.) та сучасні (20152020 рр.). Встановлено, що за орографічною приналежністю найбільша кількість скверів у Львові розташована на останцевих горбах і виступах (49,49 \% за площею), а за місцем створення - вздовж вулиць (47,06 \% за площею). 3'ясовано, що за зовнішнім виглядом у місті переважають сквери: за розміром - малої площі до 0,5 га (31,66 \% території скверів), за формою - прямокутні (39,62 \% за площею), за плануванням - регулярні (51,74 \% площі скверів) та за складом насаджень - мішані з наявністю хвойних і листяних деревних видів рослин (97,68 \% за площею). Визначено, що за функціональним призначенням більшість скверів у Львові виконують транзитну (64,74 \% за площею) та відпочинкову (53,43 \% площі скверів) функції. Встановлено, що за часом створення переважна частина скверів міста Львова сформована у другій половині ХХ ст. (68,28 \% за площею). Розроблена класифікація скверів урбанізованих територій сприятиме формуванню нових продуктивних й естетично привабливих зелених насаджень у міському середовищі та забезпечуватиме ефективне проведення заходів 3 інвентаризації насаджень комплексної зеленої зони міста Львова.

Ключові слова: зелені насадження; міські екосистеми; урбанізоване середовище; класифікаційні ознаки скверів; садовопаркові фітоценози.

Вступ. У загальній структурно-функціональній організації міських екосистем, які формують особливе урбанізоване середовище, значна частина території припадає на комплексну зелену зону, яка виконує важливі середовищетвірні і природоохоронні функції та забезпечує сприятливі умови життедіяльності людини. Серед зелених насаджень урбанізованих екосистем вагоме місце займають сквери - своєрідні "оазиси" міських територій, які штучно створені людиною для формування оптимальної ландшафтно-планувальної структури міста $[7,8,10,12]$. Сквери, як незначні за площею території (до 2,5 га), є штучно створеними об'єктами озеленення в межах міської забудови з основним призначенням короткочасний відпочинок $[1,3]$.

На відміну від паркових насаджень, сквери урбанізованих екосистем, зокрема і Львова, $є$ мало дослідженими, хоча і $\epsilon$ не менш важливими природними буферними зонами міста, які створюють особливий мікроклімат і забезпечують сприятливе середовище проживання людини.

Питання класифікації скверів міських екосистем, для подальшого формування продуктивних й естетично привабливих фітоценозів, заслуговують особливої уваги та $\epsilon$ актуальними з огляду на необхідність створення та формування незначних за площею естетично привабливих й екологічно ефективних міських зелених насаджень.

Аналіз літературних джерел. Міські території, які характеризуються взаємодією природних й антропогенних компонентів, формують своєрідну урбанізовану соціоекосистему, в якій значне місце відводять садовопарковим насадженням. Питання взаємодії різних компонентів садово-паркових екосистем в урбанізованому середовищі, а також процесів розвитку паркових і лісопаркових насаджень міських екосистем та частково скверів висвітлено у численних публікаціях вітчизняних $\mathrm{i}$ зарубіжних науковців, зокрема у працях Ю. П. Бялловича [1], О. О. Ніценка [11], Т. Г. Ларіної [9], Ю. О. Клименка [6], Я. В. Геника [4, 5], Р. Б. Дудина [2], В. П. Кучерявого [7, 8].

Значний внесок у пізнання процесів формування комплексної зеленої зони міста Львова та взаємодії різ-

Інформація про авторів:

Гринь Христина Юріївна, аспірант, кафедра ландшафтної архітектури, садово-паркового господарства та урбоекології. Email: krystinka@i.ua

Геник Ярослав В'ячеславович, д-р с.-г. наук, професор, завідувач кафедри ландшафтної архітектури, садово-паркового господарства та урбоекологіï. Email: yarhenyk@gmail.com; https://orcid.org/0000-0002-6079-6827

Цитування за ДСту: Гринь Х. Ю., Геник Я. В. Класифікації скверів та їх розподіл у комплексній зеленій зоні Львова. Науковий вісник НлтУ України. 2020, т. 30, № 2. С. 28-32.

Citation APA: Hryn, Kh. Yu., \& Henyk, Ya. V. (2020). The classifications of the squares and their distributions in the complex green area of Lviv. Scientific Bulletin of UNFU, 30(2), 28-32. https://doi.org/10.36930/40300205 
них компонентів садово-паркових екосистем зробили науковці Національного лісотехнічного університету України, Львівського національного університету ім. I. Франка та Інституту екології Карпат НАН України. У публікаціях львівських науковців проаналізовано процеси розвитку та трансформації міських фітоценозів, охарактеризовано сучасний стан, видову та просторову структуру зелених насаджень міста та розроблено заходи із підвищення естетичної привабливості зелених зон в урбанізованому середовищі.

Незважаючи на вагомість численних наукових напрацювань, питання класифікації незначних за площею зелених насаджень у міських екосистемах, формування видової, вікової та просторової структури фітоценозів парків і скверів $є$ актуальними та потребують нових наукових і практичних досліджень для формування продуктивних, естетично привабливих зелених зон в урбанізованому середовищі.

Об'єкт дослідження - сквери адміністративних районів Львова.

Предмет дослідження - методи і засоби визначення класифікаційних ознак скверів, їх приналежність до адміністративних районів і розподіл у межах ознак, груп і підгруп.

Мета дослідження - розробити класифікацію скверів Львова за певними ознаками для оптимізації процесу інвентаризації зелених насаджень комплексної зеленої зони міста та формування продуктивних й естетично привабливих садово-паркових фітоценозів.

Основними завданнями дослідження є розроблення класифікаційних ознак скверів в урбанізованих екосистемах на підставі аналізу невеликих за площею зелених насаджень Львова та їх розподіл за певними групами i підгрупами в міському середовищі.

Наукова новизна результатів дослідження - вперше проведено класифікацію скверів зеленої зони міста Львова за такими ознаками: зовнішнім виглядом, розташуванням, функціями та часом створення.

Практична значущість отриманих результатів дослідження полягає в тому, що розроблена класифікація скверів дасть змогу ефективніше аналізувати видову, вікову і просторову структури фітоценозів міських екосистем, формувати продуктивні й естетично привабливі зелені зони в урбанізованому середовищі та здійснювати процес інвентаризації насаджень комплексної зеленої зони Львова.

Методика проведення дослідження. За даними УПравління архітектури та урбаністики департаменту містобудування Львівської міської ради у Львові налічується 86 скверів загальною площею 43,4 га: у Галицькому районі міста - 34 сквери (площа 12,3 га), у Залізничному районі - 9 скверів (площа 7,6 га), у Личаківському районі - 17 скверів (площа 7,8 га), у Сихівському районі - 8 скверів (площа 4,4 га), у Франківському районі - 9 скверів (площа 5,3 га) та у Шевченківському районі міста - 9 скверів (площею 6,0 га). Наведений перелік скверів міста не $\epsilon$ вичерпним, оскільки не всі сквери в межах комплексної зеленої зони Львова перебувають на обліку - деякі зелені території втратили статус скверу, а деякі нові сквери лише на стадії створення.

Дослідження проведено виходячи із завдань системного підходу до вивчення питань щодо класифікації зелених насаджень в урбанізованих екосистемах та їх розподілу в комплексній зеленій зоні міста.
У процесі наукового пошуку, аналізу та розроблення класифікаційних ознак скверів міста Львова застосовано загальнонаукові, історико-географічні, картографічні, маршрутно-рекогносцирувальні, порівняльні та математичні методи. Особливості розташування та класифікаційні ознаки скверів Львова встановлювали під час їх натурних досліджень у різних адміністративних районах міста.

Загалом дослідженнями охоплено 34 сквери Львова загальною площею 17,0098 га (39,2 \% від загальної площі скверів), які репрезентативно представляють невеликі за площею зелені насадження міста та відображають процеси, що відбуваються у садово-паркових екосистемах урбанізованих територій.

Результати дослідження. Сквери у Львові, як компоненти комплексної зеленої зони міста, охоплюють незначні площі (від 0,060 до 2,404 га) та розташовані, зазвичай, всередині житлової забудови, вздовж вулиць і на площах. Вони є досить поширеною категорією міських насаджень, які виконують функцію своєрідної природної буферної системи та оздоровлюють середовище проживання людини. В урбанізованому середовищі сквери виконують різноманітне призначення - озеленення площ, озеленення внутрішньоквартальних територій, озеленення окремих громадських будівель і транспортних зупинок. У ролі архітектурних рішень сквери розташовані поблизу житлових й адміністративних будівель, у межах житлових і промислових кварталів.

Загалом сквери в урбанізованому середовищі, зокрема й у Львові, $є$ яскравим прикладом антропогенно створеного культурфітоценозу, оскільки представляють сукупність різних рослинних угруповань різного цільового призначення.

Значення скверів у творенні мікроклімату міста $\epsilon$ надзвичайно вагомим, оскільки вони є своєрідними фітомеліорантами урбанізованого середовища. Насадження скверів забезпечують зниження температури теплових зон у місті, підвищують відносну вологість повітря, становлять біогеохімічні бар'єри, які поглинають радіаційне, пилове та шумове забруднення, продукують кисень у процесі фотосинтезу, регулюють поверхневий стік та ерозійні процеси, а також виконують оздоровчу функцію внаслідок виділення фітонцидів. Сквери у міських екосистемах виконують також естетичну та рекреаційну функції.

На підставі проведених натурних досліджень скверів Львова та аналізу історико-географічних і картографічних матеріалів, розроблено класифікацію незначних за площею зелених насаджень міста, яка базується на різних класифікаційних ознаках (рисунок).

Запропонована класифікація поділяє сквери міста за чотирма ознаками (за зовнішнім виглядом, за розташуванням, за функціями та за часом створення), які відповідно ще детальніше поділяють на групи та підгрупи:

I. За розташуванням:

- за приналежністю до району Львова: Галицький; Залізничний Личаківський, Синівський, Франківський, Шевченківський;

- за орографічною приналежністю: улоговини, понижені рівнини, останцеві горби і виступи, плато.

- за місцем створення: на площах, на вулицях, біля громадських будівель, біля житлових будівель;

II. За зовнішнім виглядом:

- за розміром (площею): малі (до 0,5 га), середні (0,5-1,0 га), великі (1,0-2,5 га); 
- за формою: трикутні, прямокутні, округлі, витягнуті, неправильної форми;

- за плануванням: регулярні, пейзажні;

- за складом насаджень: хвойні, листяні, мішані.

III. За функціями: транзитні, відпочинкові, буферні, спортивні (біля стадіонів і спортивних майданчиків), лікар- няні (біля лікарень та медичних закладів), декоративні, пам'ятні.

IV. За часом створення: старовинні (до початку XX ст.), старі (від початку до 50-х років ХХ ст.), нові (від 50-х років до кінця ХХ ст.), новітні (2000-2015 рр.), сучасні (2015-2020 pp.).

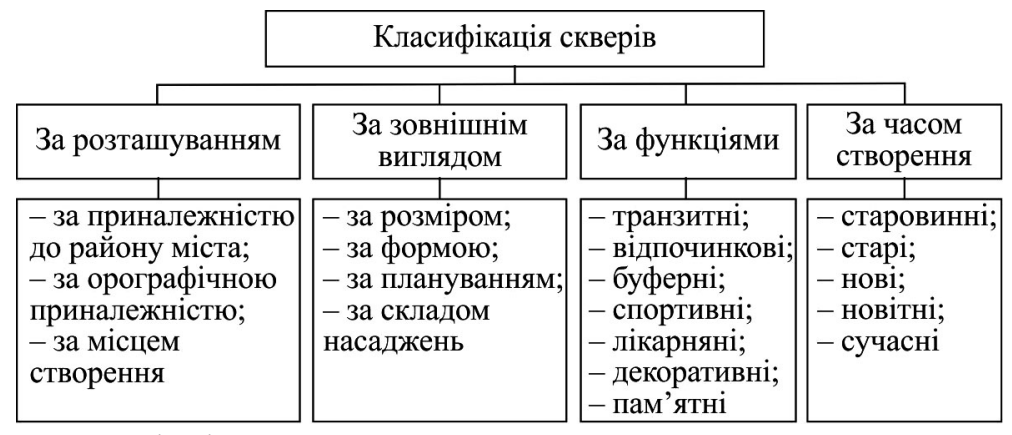

Рисунок. Класифікаційні ознаки скверів міста Львова

Розташування скверів у Львові тісно взаємопов'язане із плануванням міської забудови та розвитком конкретного адміністративного району, розміщенням громадських, промислових і житлових будівель та їх архітектурних особливостей, транспортних шляхів та щільності міської забудови. Розподіл скверів за розташуванням та приналежністю до адміністративного району міста Львова, їхні площі та номер за порядком для подальшої класифікації в межах груп і підгруп наведено в табл. 1.

Табл. 1. Приналежність скверів до адміністративних районів міста Львова та їх площі

\begin{tabular}{|c|c|c|}
\hline № & Назва скверу & \begin{tabular}{|c|}
$\begin{array}{l}\text { плеща, } \\
\text { га }\end{array}$ \\
\end{tabular} \\
\hline \multicolumn{3}{|c|}{ Франківський район } \\
\hline 1 & Сквер на вул. Японській & 0,2977 \\
\hline 2 & $\begin{array}{l}\text { Сквер на вул. Героїв УПА - вул. Кульпарківська } \\
\text { (біля Кінескопу) }\end{array}$ & 1,4546 \\
\hline 3 & Сквер на вул. І. Богуна, 11 & 0,0600 \\
\hline 4 & $\begin{array}{l}\text { Сквер "Кульпарківський" на вул. Коновальця - } \\
\text { вул. Житомирська }\end{array}$ & 1,7456 \\
\hline 5 & $\begin{array}{l}\text { Сквер на вул. Генерала Т. Чупринки (біля Фран- } \\
\text { ківської райдержадміністрації) }\end{array}$ & 0,1535 \\
\hline \multicolumn{3}{|c|}{ Сихівський район } \\
\hline 6 & Сквер біля кінотеатру ім. О. Довженка & 1,6580 \\
\hline 7 & $\begin{array}{l}\text { Сквер Гідності на просп. Червоної Калини, } 109 \\
\text { (школа № 98) }\end{array}$ & 0,3610 \\
\hline 8 & $\begin{array}{l}\text { Сквер ім. Юрія Вербицького на вул. Коломийсь- } \\
\text { кій, } 15\end{array}$ & 0,0746 \\
\hline 9 & $\begin{array}{l}\text { Сквер на перетині вул. П. Полуботка - вул. І. Ка- } \\
\text { валерідзе }\end{array}$ & 0,3814 \\
\hline \multicolumn{3}{|c|}{ Залізничний район } \\
\hline 10 & ул. Ряшівській (ліва сторона) & 0,8447 \\
\hline 11 & Сквер на вул. Ряшів & 1,2723 \\
\hline 12 & $\begin{array}{l}\text { Сквер на перетині вул. Г. Кузневича - вул. Горо- } \\
\text { доцької }\end{array}$ & 2,4040 \\
\hline & $\begin{array}{l}\text { Сквер на перетині вул. Суботівської - вул. І. Сір- } \\
\text { ка }\end{array}$ & 0,6440 \\
\hline & Сквер на вул. Сигнівці, 3 & 0,2010 \\
\hline \multicolumn{3}{|c|}{ Галицький район } \\
\hline 5 & Сквер біля пам'ятни & 0,0721 \\
\hline 16 & Сквер біля пам'ятника Дани. & 0,2147 \\
\hline 17 & Сквер на пл. А. Міцкевича & 0,1744 \\
\hline 18 & Сквер на пл. М. Шашкевича & 0,1909 \\
\hline 19 & Сквер на пл. Різні & 0,2530 \\
\hline 20 & Сквер на пл. І. Фрағ & 0,0600 \\
\hline 21 & Сквер на пл. Соборній & 0,1526 \\
\hline 22 & Сквер на пл. Ринок & 0,1045 \\
\hline
\end{tabular}

\begin{tabular}{|l|l|c|}
\hline 23 & Сквер на пл. Святого Юра & 1,0640 \\
\hline 24 & Сквер на просп. Т. Шевченка & 0,3939 \\
\hline \multicolumn{3}{|c|}{ Шевченківський район } \\
\hline 25 & $\begin{array}{l}\text { Сквер на перетині вул. Варшавської - вул. Сос- } \\
\text { нової }\end{array}$ & 0,3467 \\
\hline 26 & $\begin{array}{l}\text { Сквер на вул. Гетьмана I. Мазепи, 3-б } \\
\text { (навколо статуї Матері Божої) }\end{array}$ & 0,3000 \\
\hline 27 & $\begin{array}{l}\text { Сквер "Замарстинівській" № 1 на перетині вул. } \\
\text { Замарстинівської - вул. В. Липинського }\end{array}$ & 0,0606 \\
\hline 28 & $\begin{array}{l}\text { Сквер "Замарстинівській" № 2 на перетині вул. } \\
\text { Замарстинівської - вул. В. Липинського }\end{array}$ & 0,1862 \\
\hline 29 & $\begin{array}{l}\text { Сквер "Замарстинівській" № 3 на перетині вул. } \\
\text { Замарстинівської - вул. В. Липинського }\end{array}$ & 0,3834 \\
\hline \multicolumn{3}{|c|}{ Личаківський район } \\
\hline 30 & Сквер на вул. Водогінній, 2 & 0,4302 \\
\hline 31 & Сквер на вул. М. Заньковецької & 0,1892 \\
\hline 32 & Сквер біля будинку № 14 на вул. М. Лисенка & 0,1900 \\
\hline 33 & Сквер на вул. Студентській & 0,1529 \\
\hline 34 & Сквер на пл. С. Петрушевича & 0,5381 \\
\hline \multicolumn{2}{|c|}{ Загальна площа скверів } \\
\hline
\end{tabular}

За дослідженнями 34 скверів міста Львова загальною площею 17,0098 га встановлено, що найбільша їх кількість (10 скверів, або 29,41 \% від кількості) загальною площею 2,6801 га розташована в Галицькому районі міста. Найбільша площа скверів $є$ у Залізничному (5,3660 га, або 31,55 \% площі) та Франківському (3,7114 га, або 21,82 \% площі) районах міста.

Сквери міста розташовані у різних природно-географічних районах Львова - Львівське Розточчя (північна та північно-західна частина міста), Грядове Побужжя (північно-східна частина міста), Львівське плато (південна частина міста), Любінсько-Волинська рівнина (південно-західна частина міста) та Львівська улоговина або долина річки Полтви (центральна та східна частини міста). Природно-географічна та орографічна приналежність скверів безпосередньо впливає на формування їхніх фітоценозів та видовий склад зелених насаджень. Класифікацію скверів за розташуванням, а саме за орографічною приналежністю та за місцем створення наведено в табл. 2.

За орографічною приналежністю найбільша кількість скверів Львова розташована на останцевих горбах і виступах - 15 скверів (44,12 \% від кількості), що загалом становить 8,4182 га, або 49,49 \% від загальної площі. За місцем створення найбільша кількість скверів міста розташована вздовж вулиць - 16 скверів (47,06 \% 
від кількості) загальною площею 10,8314 га (63,68 \% площі досліджених скверів).

На зовнішній вигляд скверу, як антропогенно створеного комплексу зелених насаджень, вагомий вплив чинять транспортні (пішохідний рух, зупинки громадського транспорту, дорожня мережа), функціональ- ні (цільове призначення скверу) та архітектурно-композиційні (розміри, призначення та конфігурація ділянки, на якій розташований сквер) особливості міста. Класифікацію скверів міста Львова за зовнішнім виглядом наведено у табл. 3.

Табл. 2. Класифікація скверів Львова за орографічною приналежністю та місцем зростання

\begin{tabular}{|c|c|c|c|}
\hline Класифікаційна ознака & Класифікаційна група & Класифікаційна підгрупа & Номер скверу за порядком у табл. 1 \\
\hline \multirow{8}{*}{ За розташуванням } & \multirow{4}{*}{$\begin{array}{c}\text { за орографічною } \\
\text { приналежністю }\end{array}$} & улоговини & $15,16,17,18,19,21,22,24,33,34$ \\
\hline & & понижені рівнини & $10,11,12,13,14$ \\
\hline & & останцеві горби і виступи & $1,2,3,4,5,6,7,8,9,18,23,25,27,28,29$ \\
\hline & & плато & $20,30,31,32$ \\
\hline & \multirow{4}{*}{ за місцем створення } & на площах & $16,17,18,19,20,21,22,23,34$ \\
\hline & & на вулицях & $1,2,4,10,11,12,13,15,24,26,27,28,29,30,31,33$ \\
\hline & & біля громадських будівель & $5,6,7,9,14$ \\
\hline & & біля житлових будівель & $3,15,25,32$ \\
\hline
\end{tabular}

Табл. 3. Класифікація скверів Львова за зовнішнім виглядом

\begin{tabular}{|c|c|c|c|}
\hline Класифікаційна ознака & Класифікаційна група & Класифікаційна підгрупа & Номер скверу за порядком у табл. 1 \\
\hline \multirow{13}{*}{ За зовнішнім виглядом } & \multirow{3}{*}{ за розміром (площею) } & малі & $\begin{array}{c}1,3,5,7,8,9,14,15,16,17,18,19,20,21,22,24 \\
25,26,27,28,29,30,31,32,33\end{array}$ \\
\hline & & середні & $10,13,34$ \\
\hline & & великі & $2,4,6,11,12,23$ \\
\hline & \multirow{5}{*}{ за формою } & трикутні & $9,10,20,33$ \\
\hline & & прямокутні & $1,2,4,7,11,13,15,16,22,29,32$ \\
\hline & & округлі & $3,8,17,18,23,26,31$ \\
\hline & & витягнуті & $14,21,24,25,34$ \\
\hline & & неправильної форми & $5,6,12,19,27,28,30$ \\
\hline & \multirow[t]{2}{*}{ за плануванням } & регулярні & $\begin{array}{c}1,2,5,6,7,13,15,16,17,18,20,22,23,24,25,26, \\
30,32,33,34\end{array}$ \\
\hline & & пейзажні & $3,4,8,9,10,11,12,14,19,21,27,28,29,31$ \\
\hline & \multirow{3}{*}{ за складом насаджень } & хвойні & - \\
\hline & & листяні & 24 \\
\hline & & мішані & ,25-34 \\
\hline
\end{tabular}

За розміром у Львові переважають сквери малої площі (до 0,5 га) - 25 об'єктів досліджень $(73,53 \%$ від кількості) загальною площею 5,3845 га (31,66 \% площі скверів). За формою у місті переважають сквери прямокутної форми - 11 об'єктів досліджень (32,35\% від кількості), що загалом становить 6,7399 га, або 39,62 \% від загальної площі.

За плануванням, що поділяє сквери міста на регулярні та пейзажні, за кількістю та площею переважають регулярні сквери - 20 об'єктів досліджень $(58,82 \%$ від кількості) загальною площею 8,8012 га (51,74 \% площі скверів). Регулярні прийоми планування скверу здебільшого застосовують у разі його розташування на центральній площі чи перед великими громадськими будівлями.

За складом насаджень у Львові переважають сквери, у яких зростають і листяні, і хвойні деревні види рослин - 33 сквери (97,06 \% від кількості) загальною площею 16,6159 га (97,68 \% площі скверів). Сдиний сквер на проспекті. Т. Шевченка характеризується наявністю в насадженні тільки листяних деревних видів рослин, а сквери, в яких зростають тільки хвойні деревні рослини, у місті відсутні.

Сквери міста Львова переважно виконують кілька функцій відповідно до свого цільового призначення, а також залежно від території розташування. Класифікацію об'єктів дослідження, скверів міста, за функціями наведено у табл. 4. Більшість скверів у Львові виконують транзитну (16 об'єктів дослідження загальною площею 9,3105 га) та відпочинкову (14 об'єктів загальною площею 9,0883 га) функції. Спортивну функцію виконує тільки один сквер невеликої площі, розташований на перетині вул. Варшавської - вул. Соснової (площа 0,3467 га).

Сквери у Львові створювали у різний період часу, що пов'язано із розбудовою міста, розширенням його меж та збільшенням площі. Перші сквери створено у центральній історичній частині міста ще до початку XX ст. Розподіл скверів Львова за часом створення наведено в табл. 5.

Табл. 4. Класифікація скверів Львова за функціями

\begin{tabular}{|c|c|c|}
\hline \multicolumn{2}{|c|}{ Класифікаційна: } & \multirow{2}{*}{ Номер скверу за порядком у табл. 1} \\
\hline ознака & група & \\
\hline \multirow{7}{*}{ 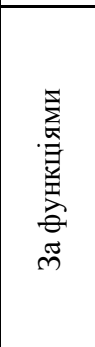 } & транзитна & $\begin{array}{c}2,6,8,9,12,13,15,19,20,22,23,24 \\
25,27,28,33\end{array}$ \\
\hline & відпочинкова & 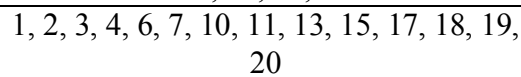 \\
\hline & буферна & $2,4,9,12,14,21,22,25,32$ \\
\hline & спортивна & 25 \\
\hline & лікарняна & - \\
\hline & декоративна & $6,7,15,17,19,22,26,31$ \\
\hline & пам'ятна & $13,15,16,17,18$ \\
\hline
\end{tabular}

Табл. 5. Класифікація скверів Львова за часом створення

\begin{tabular}{|c|c|c|}
\hline \multicolumn{2}{|r|}{ Класифікаційна: } & \multirow{2}{*}{\begin{tabular}{|c|} 
Номер скверу за порядком у \\
табл. 1 \\
\end{tabular}} \\
\hline нака & група & \\
\hline \multirow{5}{*}{ 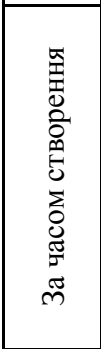 } & $\begin{array}{c}\text { старовинні } \\
\text { (до початку XX ст.) }\end{array}$ & $16,21,22,23,24$ \\
\hline & $\begin{array}{c}\text { старі (від початку до } \\
\text { 50-х років XX ст.) }\end{array}$ & 18,20 \\
\hline & $\begin{array}{c}\text { нові (від } 50-\mathrm{x} \mathrm{років} \mathrm{до} \\
\text { кінця XX ст.) }\end{array}$ & $\begin{array}{c}2,3,4,5,10,11,12,13,14 \\
15,17,25,26,27,28,29,30 \\
32,33,34\end{array}$ \\
\hline & новітні (2000-2015 pр.) & $5,6,8,19$ \\
\hline & сучасні (2015-2020 рр.) & $1,7,9,31$ \\
\hline
\end{tabular}

Scientific Bulletin of UNFU, 2020, vol. 30, no 2 
За часом створення у Львові переважають нові сквери, які сформовано у другій половині XX ст. -20 об'єктів загальною площею 11,6143 га $(68,28$ \% від площі досліджених скверів). Упродовж останніх п'яти років у місті створено сучасні сквери - на вул. Японській, на просп. Червоної Калини (поблизу школи № 98), на перетині вул. П. Полуботка та вул. І. Кавалерідзе та на вул. М. Заньковецької.

Класифікація скверів міста Львова за ознаками групами та підгрупами сприятиме формуванню нових продуктивних й естетично привабливих зелених насаджень у міському середовищі та забезпечуватиме ефективне проведення заходів з інвентаризації насаджень зеленої зони Львова.

Висновки. Сквери Львова, як і інші зелені насадження міста, виконують важливі середовищетвірні і природоохоронні функції, формують особливий мікроклімат та забезпечують сприятливе середовище проживання людини.

Класифікацію скверів здійснено за такими ознаками: зовнішнім виглядом, розташуванням, функціями та часом створення. Класифікаційні ознаки відповідно поділяли на групи та підгрупи.

За орографічною приналежністю найбільша кількість скверів у Львові розташована на останцевих горбах і виступах та улоговинах, за місцем створення - уздовж вулиць та на площах.

За зовнішнім виглядом у місті переважають сквери малої площі (до 0,5 га), прямокутної форми, регулярного планування 3 наявністю у видовому складі хвойних і листяних деревних рослин.

Сквери Львова переважно виконують декілька функцій відповідно до свого цільового призначення. Більшість скверів у місті виконують транзитну та відпочинкову функції.

Більшість скверів у Львові створено у другій половині XX ст. Значну частину скверів створено впродовж останніх двадцяти років за розробленими новими проектами в контексті планів розвитку міста.
Розроблена класифікація скверів міста дасть змогу ефективніше аналізувати видову, вікову і просторову структури фітоценозів міських екосистем, формувати продуктивні й естетично привабливі зелені зони в урбанізованому середовищі та здійснювати процес інвентаризації насаджень комплексної зеленої зони Львова.

\section{References}

1. Byallovich, Yu. P. (1939). K teorii fitokulturnyih landshaftov. Izvestiya Gosudarstvennogo geograficheskogo obschestva, 4, 559587. [In Russian].

2. Dudyn, R. B. (2016). Konservaciia, restavraciia i rekonstrukciia sadovo-parkovykx obiektiv. Lviv: Manuskrypt, 216 p. [In Ukrainian].

3. Gostev, V. F., \& Yuskevich, N. N. (1991). Proektirovanie sadov i parkov. Moscow: Stroyizdat, 345 r. [In Russian].

4. Henyk, Ya. V. (2013) Chynnyky transformatsiinykh protsesiv u nasadzhenniakh kompleksnykh zelenykh zon urbanizovanykh ecosystem. Scientific Bulletin of UNFU, 23(2), 113-118. [In Ukrainian].

5. Henyk, Ya. V., Dudyn, R. B., Dyda, A. P., Marutyak, S. B., \& Kaspruk, O. I. (2017). Transformatsiyni protsesy v lisoparkovykh i parkovykh nasadzhennyakh urbanizovanykh ekosistem Zakhodu Ukrayiny. Scientific Bulletin of UNFU, 27(10), 9-15. [In Ukrainian]. https://doi.org/10.15421/40271001

6. Klimenko, Yu. O., \& Kuznetsov, S. I. (2015). Zagalne parkoznavstvo (istorichni, bIologo-ekologichni, landshaftno-lisivnichi pidhody ta metody). Kyiv: Komprint, 415 r. [In Ukrainian].

7. Kucheriavyi, V. P. (2008). Sadi i parki Lvova. Lviv: Novyy svit2000, 360 p. [In Ukrainian].

8. Kucheriavyi, V. P., \& Kucheriavyi, V. S. (2019). Ozelenennya naselenykh mists. Lviv: Novyy svit-2000, 620 p. [In Ukrainian].

9. Larina, T. G. (1987). Geobotanicheskoe izuchenie parkovyih kulturfitotsenozov kak metod vyiyavleniya ih ustoychivosti. Bulletin of the Main Botanical Garden, 144, 59-64. [In Russian].

10. Lihocheva, E. A., Timofeev, D. A. \& Zhidkov, M. P. (1996). Gorod - ekosistema. Moscow: Media-PRESS, 204 r. [In Russian].

11. Nitsenko, A. A. (1969). Sady i parki kak obektyi geobotanicheskogo issledovaniya. (Ser.: Biologicheskaya). Scientific Bulletin of $L G U, 3(15), 35-41$. [In Russian].

12. Reymers, N. F. (1992). Ohrana prirodyi i okruzhayuschey cheloveka sredyi: slovar-spravochnik. Moscow: Prosveschenie, 318 r. [In Russian].

\title{
Kh. Yu. Hryn, Ya. V. Henyk \\ Ukrainian National Forestry University, Lviv, Ukraine
}

\section{THE CLASSIFICATIONS OF THE SQUARES AND THEIR DISTRIBUTIONS IN THE COMPLEX GREEN AREA OF LVIV}

\begin{abstract}
The results of studies of a representative sample of Lviv squares are presented and their role in an urbanized environment is highlighted. Based on field studies and cartographic materials, the classification of Lviv city squares by characteristics - appearance, location, functions and time of creation, as well as by groups and subgroups - has been developed. The number, area and affiliation of the city squares to the administrative districts of Lviv are given. The squares are classified by orographic affiliation and place of creation. The distribution of city squares by appearance - by size, area, shape, planning and composition of plantations is carried out. The Lviv squares are classified according to their functions - transit, recreation, buffer, sports, hospital, decorative, commemorative, as well as the time of creation - ancient (up to the beginning of the twentieth century), old (from the beginning to the $1950 \mathrm{~s}$ ), new (from the $1950 \mathrm{~s}$ to the end of the twentieth century), the latest (2000-2015) and the modern (2015-2020). The largest number of squares in Lviv is found on orographic affiliations in the relict hills and ridges (49,49\% by area), and at the place of creation - along the streets $(47,06 \%$ by area). It is found that the appearance of the city is dominated by squares: in size - a small area of up to 0,5 hectares $(31,66 \%$ of the territory of the squares), rectangular in shape $(39,62 \%$ in area), regular $(51,74 \%$ of the area of the squares) and the composition of the plantations - mixed with the representation of coniferous and deciduous tree species of plants ( $97,68 \%$ by area). It is determined that by function purpose, most squares in Lviv perform transit (64,74 \% by area) and recreational (53,43\% of squares) functions. It is established that by the time of creation, most of the squares of Lviv were formed in the second half of the twentieth century $(68,28 \%$ by area). The developed classification of squares of urbanized territories will facilitate the formation of new productive and aesthetically attractive green spaces in urban environment and will ensure the effective implementation of measures for the inventory of plantations of the complex green area of Lviv.
\end{abstract}

Keywords: green spaces; urban ecosystems; urban environment; classification features of squares; landscape park phytocenoses. 